\title{
Detection of Telomerase Activity in Plasmodium falciparum Using a Nonradioactive Method
}

\author{
Claudia C Rubiano, Moises Wasserman ${ }^{+}$
}

\begin{abstract}
Laboratorio de Bioquímica, Instituto Nacional de Salud, Bogotá, Colombia and Laboratorio de Investigaciones Básicas en Bioquímica, Departamento de Química, Facultad de Ciencias, Universidad Nacional de Colombia, Bogotá, Colombia
\end{abstract}

A simple, quick and sensitive method was used to detect telomerase activity in Plasmodium falciparum. The telomeric repeat amplification protocol (TRAP assay) was modified using electrophoresis and staining with SYBRgreen I to detect telomerase activity in a range of $10^{2}$ to $10^{7}$ parasites. This might be a useful way to ascertain telomerase activity in different types of nontumor cells.

Key words: Plasmodium - malaria - telomerase - assay - nonradioactive

Telomerase is the enzyme responsible for compensating DNA loss at the ends of linear chromosomes in most eukaryotic cells (Greider \& Blackburn 1985, Greider 1996). It is a reverse transcriptase with its own RNA, which it uses as a template to synthesize the telomeric repeats over again (Blackburn et al. 2000). Telomerase activity has been detected in $85-90 \%$ of human tumors and cell lines derived from tumors (Counter et al. 1994, Kim et al. 1994, Landberg et al. 1997) and it was proposed that its inhibition could detain growth, primarily in cells with high replication rates (Herbert et al. 1999, Liu 1999).

The telomeric repeat amplification protocol (TRAP assay) (Kim et al. 1994) and several of its modified versions have become the standard method for measuring telomerase activity in different types of cells. This assay involves elongation by telomerase of a primer that simulates the telomeric end, followed by amplification of the elongated products in a polymerase chain reaction (PCR) with a reverse primer complementary to the elongated telomeric repeats (see Fig. 1).

Using the TRAP assay, telomerase activity has been detected in Plasmodium falciparum, which is the parasite responsible for the most severe form of malaria in human beings. This has been accomplished through radioactive labeling of the products obtained (Bottius et al. 1998, Sriwilaijareon et al. 2002) or by using the kit TRAP-eze (Oncor, Gaithersburg, MD) (Aldous et al. 1998). This kit uses primers that are not specific for P. falciparum, whose telomeric repeats differ from other eukaryotes. In the present study, telomerase activity in P. falciparum was detected using the TRAP assay with specific primers for

This work was supported by the Instituto Nacional de Salud, by the Universidad Nacional de Colombia, project DINAIN 2010100198 and by the Instituto Colombiano para el Fomento de la Ciencia y la Tecnología Colciencias project 1101-05-11422.

+ Corresponding author. E-mail: mwasser@ciencias.unal.edu.co Received 24 January 2003

Accepted 18 June 2003
Plasmodium and staining the products with SYBR-green I stain (Molecular Probes, Inc. Eugene, Oregon US), which is a highly sensitive method, already used to detect very low quantities of DNA (Karlsen et al. 1995, Schneeberger et al. 1995, Perkins. 2001, Aldea et al. 2002, Polanco et al. 2002).

Parasites of the FCB-2 strain, cultivated according to the Trager and Jensen (1976) method, were used to prepare the protein extracts. Although not stringently synchronized, the majority of the parasites $(80-90 \%)$ corresponded to trophozoites between $36-40 \mathrm{~h}$ old. The infected erythrocytes were isolated from the culture medium through centrifugation $(2500 \mathrm{x} \mathrm{g}, 10 \mathrm{~min})$ and washed with HBS isotonic buffer (20 mM HEPES pH 7.4, $160 \mathrm{mM} \mathrm{NaCl}$ ). The parasites were freed from the erythrocytes through lysis with $0.15 \%$ saponin in HBS $\left(4^{\circ} \mathrm{C}, 15 \mathrm{~min}\right)$ and centrifugation $(15000 \mathrm{xg}, 15 \mathrm{~min})$. The parasite pellet was washed two or three times with HBS $(10000 \mathrm{x} \mathrm{g}, 5 \mathrm{~min})$ and $1 / 100 \mathrm{vol}$. of a mixture of protease inhibitors was added $(1 \mathrm{mg} / \mathrm{ml}$ pepstatin A, $1 \mathrm{gm} / \mathrm{ml}$ leupeptin, $1 \mathrm{mg} / \mathrm{ml}$ aprotinium, $0.1 \mathrm{mg} / \mathrm{ml}$ phenantroline, and $1 \mathrm{mM}$ Benzamidine-HCI) as well as an RNase inhibitor (40U RNase-out, BRL). It was then stored at $-70^{\circ} \mathrm{C}$ until extraction.

The parasite pellet was resuspended in 200-400 $\mu$ l of TMG buffer (10 mM Tris HCI pH 7.5, $\mathrm{mM} \mathrm{MgCl}_{2}, 10 \%$ glycerol, $10 \mathrm{mM} \beta$-mercaptoethanol), and $1 / 10$ of $2 \%$ nonidet P40 in TMG buffer was added to lyse the parasites. The mixture was shaken for $30 \mathrm{~min}$ at $4^{\circ} \mathrm{C}$, then subjected to ultracentrifugation at $100000 \mathrm{x} \mathrm{g}$, at $4^{\circ} \mathrm{C}$ for $1 \mathrm{~h}$. The S100 supernatant or fraction was stored at $-70^{\circ} \mathrm{C}$ until its use. The protein concentration was determined by the Bradford method, using bovine serum albumin (BSA) in TMG buffer for the calibration curve.

The PfTS- 1 and PfCX primers described by Bottius et al. (1998), were used for the TRAP assay. They are specific for P. falciparum. The PfTS-1 primer (5' AATCCGTC GAGCAGAGTTCA 3'), which acts as a substrate for the telomerase, contains specific P. falciparum telomere

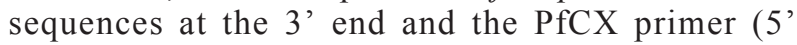
GGCGCGT/GAAACCCTG/AAACCCTG/AAACCC 3'), 


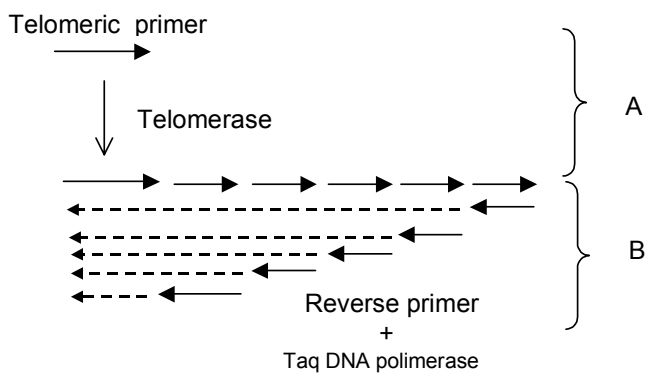

Fig. 1: telomeric repeat amplification protocol (TRAP assay) for the detection of telomerase activity. The assay involves two steps. A: the telomerase elongates a forward primer that simulates the telomere end; B: a reverse primer that is complementary to the telomere repeat is added and a polymerase chain reaction is carried out.

which acts as a reverse primer for amplification, has 3 repeats complementary to the $P$. falciparum telomeric repeats and a GC clamp on the 5' end.

The reactions were carried out on a total volume of $50 \mu \mathrm{l}$ which contained TRAP buffer $(20 \mathrm{mM}$ Tris $\mathrm{HCI} \mathrm{pH}$ $8.3,1.5 \mathrm{mM} \mathrm{Mg} \mathrm{Cl} 2,0.005 \%$ Tween 20, 1 mM EGTA, 0.2 $\mathrm{mg} / \mathrm{ml} \mathrm{BSA}$ ), $50 \mu \mathrm{M}$ dNTPs, $5 \mathrm{U}$ of RNase inhibitor (RNaseout, BRL), $0.1 \mu \mathrm{g}$ of PfTS-1 primer and parasite protein extract (S100 fraction). This mixture was incubated for $1 \mathrm{~h}$ at $37^{\circ} \mathrm{C}$ to allow the telomerase to elongate the primer, before adding $2.5 \mathrm{U}$ of Taq DNA polymerase (Promega) and $0.1 \mu \mathrm{g}$ of the PfCX primer to carry out the PCR reaction, which consisted of 35 denaturation cycles at $94^{\circ} \mathrm{C} \times 10 \mathrm{~s}$, annealing at $55^{\circ} \mathrm{C} \times 30 \mathrm{~s}$ and extension at $72^{\circ} \mathrm{C} \times 1 \mathrm{~min}$. An extract previously treated with $10 \mu \mathrm{g}$ of RNase A for 30 $\min$ at $37^{\circ} \mathrm{C}$ and a reaction without the protein extract were included as controls.
Once the reactions were completed, a non-denaturant electrophoresis was done on $15 \%$ polyacrylamide gels in $0.5 \times$ TBE buffer ( $44.5 \mathrm{mM}$ Tris HCI, $44.5 \mathrm{mM}$ boric acid, $1 \mathrm{mM}$ EDTA pH 8.3). Subsequent to electrophoresis, the gels were immersed for $30 \mathrm{~min}$ in a solution of SYBR-green I stain (Molecular Probes), which was prepared in TBE $0.5 \mathrm{x}$ buffer according to the manufacturer's recommendations, then visualized at UV $(254 \mathrm{~nm})$. The images were processed using the ONE-D-Scan (Scanalytics $\odot$, CSPI division, US) program.

The assays were considered positive when a ladder of products was observed with a difference of approximately $6 \mathrm{nt}$ between the bands above $50 \mathrm{pb}$, as illustrated in Fig. $2 \mathrm{~A}$, where the reactions were done using protein extracts equivalent to $10^{5}$ and $10^{6}$ parasites.

For an idea of the sensitivity of detection by this method, the TRAP assay was carried out with protein extract in amounts corresponding to a range of $10^{2}$ to $10^{7}$ parasites (see Fig. 2B). When the number of parasites is high $\left(10^{7}\right)$, the signals diffuse and one obtains a smear more than a ladder of bands. Reducing the number of parasites gives a better definition of the signals, with the equivalent of $10^{6}$ to $10^{5}$ parasites being the optimum number for observing the signals. Below this number; that is from $10^{4}$ to $10^{2}$, the products can be observed, but with less intensity and definition.

Although there have been some reports to date of electrophoretic detection of telomerase activity using nonradioactive methods (Fujita et al. 1998, Dalla Torre et al. 2000, Zhang et al. 2000), they have been applied to tumor cells or transformed cell lines where telomerase activity is significantly higher than in other types of cells. In this respect, the present study shows it is possible to evidence telomerase activity effectively in nontumor cells,

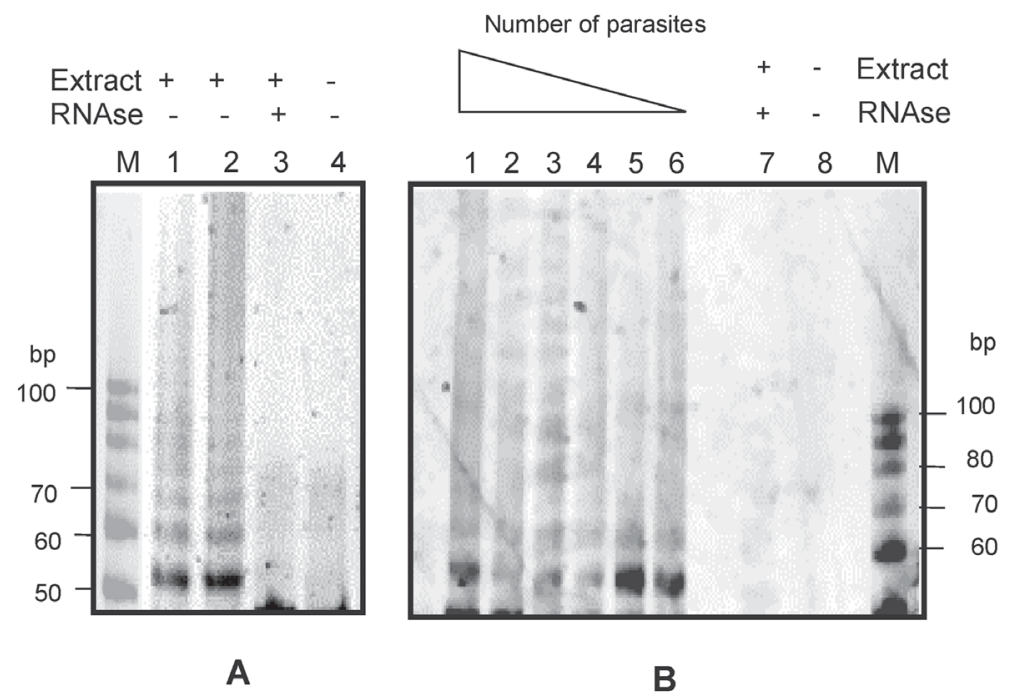

Fig. 2: detecting telomerase activity in Plasmodium falciparum using a nonradioactive method. A: the products from the telomeric repeat amplification protocol (TRAP assay) were run in a $15 \%$ polyacrylamide gel and stained with SYBR-Green I stain (Molecular Probes). Lanes 1 and 2 pertain to the test with extract equivalent to $10^{6}$ and $10^{5}$ parasites, respectively. The controls treated with RNase (lane 3 ) or without extract (lane 4) are indicated. Lane $\mathrm{M}$ corresponds to the size marker, which was a 10 bp ladder (Promega); B: to evaluate the sensitivity of the method, samples containing between $10^{7}$ and $10^{2}$ parasites (lanes 1 to 6 respectively) were used in the TRAP assay. Lane 7 corresponds to a control reaction with an RNase treated extract, lane 8 is a control reaction without protein extract, lane $\mathrm{M}$ corresponds to the size marker, which was a $10 \mathrm{bp}$ ladder (Promega). 
using a nonradioactive method.

Detecting telomerase activity is an important and necessary step in studies associated with this enzyme and its implications on cell proliferation. It is, therefore, convenient to have a simple and adequate method for this purpose. With nonradioactive detection, the TRAP assay becomes an easy-to-use tool; that is, a simple, quick and sensitive way to detect telomerase activity in protozoan parasites and possibly in other nontumor cells.

\section{REFERENCES}

Aldea C, Alvarez C, Folgueira L, Delgado R, Otero J 2002. Rapid detection of herpes simplex virus DNA in genital ulcers by real-time PCR using SYBR green I dye as the detection signal. J Clin Microbiol 40: 1060-1062.

Aldous W, Martin R, Kyle D 1998. Stage specific detection and inhibition studies of Plasmodium falciparum telomerase. Mol Biochem Parasitol 95: 281-285.

Blackburn E, Gilley D, Ware T, Bhattacharyya A, Kirk K, Wang H 2000. Studying the telomerase RNA in Tetrahymena. Methods Cell Biol 62: 417-432.

Bottius E, Bakhsis N, Sherf A 1998. Plasmodium falciparum telomerase: de novo telomere addition to telomeric and nontelomeric sequences and role in chromosome healing. Mol Cell Biol 18: 919-925.

Counter C, Hirte H, Bacchetti S, Harley C 1994. Telomerase activity in human ovarian carcinoma. Proc Natl Acad Sci USA 91: 2900-2904.

Dalla Torre C, Maciel R, Pinheiro N, Andrade J, de Toledo S, Villa L, Cerutti J 2000. TRAP-silver staining, a highly sensitive assay for measuring telomerase activity in tumor tissue and cell lines. Braz J Med Biol Res 35: 65-68.

Fujita M, Tomita S, Ueda Y, Fujimori T 1998. Gel staining methods for detection of telomerase activity with the telomeric repeat amplification protocol (TRAP) assay. Mol Pathol 51:342.

Greider C 1996. Telomere length regulation. Ann Rev Biochem 65: 337-365.

Greider C, Blackburn E 1985. Identification of a specific telomere terminal transferase activity in Tetrahymena extracts. Cell 43: 405-413.

Herbert B, Pitts A, Baker S, Hamilton S, Wright W, Shay J, Corey D 1999. Inhibition of human telomerase in immortal human cells leads to progressive telomere shortening and cell death. Proc Natl Acad Sci USA 96: 14276-14281.

Karlsen F, Steen H, Nesland J 1995. SYBR green I DNA staining increases the detection and sensitivity of viruses by polymerase chain reaction. $J$ Virol Methods 55: 153-156.

Kim N, Piatyszek M, Prowse K, Harley C, West M, Ho P, Coviello G, Wright W, Weinrich S, Shay J 1994. Specific association of human telomerase activity with immortal cells and cancer. Science 266: 2011-2015.

Landberg G, Nielsen N, Nilsson P, Emdin S, Cajander J, Roos G 1997. Telomerase activity is associated with cell cycle deregulation in human breast cancer. Cancer Res 57: 549-554.

Liu J 1999. Studies of the molecular mechanisms in the regulation of telomerase activity. FASEB J 13: 2091-2104.

Perkins EJ 2001. Enhanced detection of multiplex PCR products using SYBR Green I and an automated DNA sequencer. Biotechniques 31:278-280.

Polanco J, Rodriguez J, Corredor V, Patarroyo M 2002. Plasmodium vivax: parasitemia determination by real-time quantitative PCR in Aotus monkeys. Exp Parasitol 100: 131-134.

Schneeberger C, Speiser P, Kury F, Zeillinger R 1995. Quantitative detection of reverse transcriptase-PCR products by means of a novel and sensitive DNA stain. PCR Methods Appl 4: 234-238.

Sriwilaijareon N, Petmitr S, Mutirangura A, Ponglikitmongkol M, Wilairat P 2002. Stage specificity of Plasmodium falciparum telomerase and its inhibition by berberine. Parasitol Int 51: 99-103.

Trager W, Jensen J 1976. Human malarial parasites in continuous culture. Science 193: 673-675.

Zhang R, Wang X, Yuan J, Guo L, Xie H 2000. Using a nonradioisotopic, quantitative TRAP-based method detecting telomerase activities in human hepatoma cells. Cell Res 10: 71-77. 